\title{
STUDY ON THE TOXIC EFFECTS OF HEAVY METALS IN SEDIMENTS AND WATER OF RIVER GANGA
}

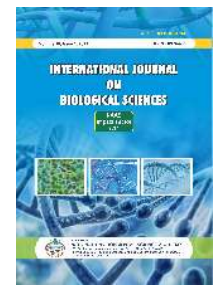

Indrani Dubey

Department of Zoology, DBS College, Kanpur (U.P.)

\section{Research Paper}

\begin{abstract}
The Ganga is one of the most sacred and worshipped river of India, is regarded as the cradle of Indian civilization. Uttar Pradesh the largest state of India is blessed with the most holy and important river in its region but due to increased urbanization and industrialization this river is under intimidation of high water pollution. The major objectives of the present study were to investigate heavy metal's concentration in water and sediments of the River Ganga. Water and sediments collected from different locations were analysed for Iron ( $\mathrm{Fe}$ ), Chromium ( $\mathrm{Cr}$ ), Lead ( $\mathrm{Pb})$, Nickel( $\mathrm{Ni})$ and Zinc(Zn). The concentration of these heavy metals in the study area indicates that the river is highly polluted. The possible sources of these heavy metal pollutants are diverse, originated from natural or anthropogenic sources and point sources.Theconcentrations determined were more than the maximum admissible and desirable limit when compared with the National and International organizations like WHO, USEPA. Exposure to heavy metals has been linked to chronic and acute toxicity developing retardation, neurotoxicity, kidney damage, various cancers, liver damage, lung damage, and fragile bones and even death in instances of very high exposure.
\end{abstract}

Keywords: Heavy metals, water, sediment, Health hazards.

\section{INTRODUCTION}

Water is the most key resource required to sustain the life on this planet. Ganga is the largest riverine system of India with well-developed ecosystem and has several important cultural, economic and environmental values. It provides water for approximately 450 million people with an over 550 individuals per square kilometer (Behera et al., 2011). Therefore, the river water is being utilized for fishing, aquaculture, irrigation and domestic purposes, river basin for cultivation of vegetables and cereals. The Ganga basin is among the most heavily populated areas in the world with an average density of 520 persons $/ \mathrm{km} 2$ (Das and Tamminga, 2012). The basin sustains more than 300 million people in India, Nepal and Bangladesh (Gopal, 2000; Goswami et al., 2021). The basin of river Ganga, which has very rich heritage, cultural and religious values, drains about 1,060,000 $\mathrm{km}^{2}$ area and it is the fifth largest in the world (Welcomme, 1985). The river system drains about one-fourth of the Indian subcontinents. In India, the river Ganga passes along 29 class I cities, 23 class II cities and approximately 50 towns because of which Ganga water is continuously degrading due to direct discharge of industrial wastes, agricultural run of and anthropogenic activity along the river bank (Singh and Verma, 2016). Such activity culminates into the accumulation of domestic, industrial and agricultural wastes in the river (Kalal et al., 2021). These wastes along with electronic wastes contain health hazard chemicals like salts of chromium, copper, cadmium, arsenic, mercury and lead which interact with aquatic environments and affect the river ecosystem and public health (Verma and Prakash, 2020).

*Corresponding author: indranidubey31@gmail.com 
The river Ganga originates from the Gangotri glacier at Gaumukh in the UttarKashi district of Uttarakhand province in India, at an altitude of about $3800 \mathrm{~m}$ above mean sea level in the Garhwal Himalaya .The length of the main channel from the traditional source of the Gangotri glacier in India is about $2550 \mathrm{~km}$. After flowing through the Shivalik hills it enters plains at Haridwar. Then it flows southwards, passing through the plains of Uttar Pradesh. After leaving Uttar Pradesh, the Ganga enters Bihar in the Rohtas district. From Bihar, it enters West Bengal province and starts flowing south. Nearly $40 \mathrm{~km}$ below Farakka it is divided into two arms. The left arm flows eastwards into Bangladesh and the right arm, called Bhagirathi, continues to flow south through West Bengal. The Bhagirathi flowing west and south-west of Kolkata is known as Hooghly. After reaching Diamond Harbour, it attains a southward direction and is split into two streams before reaching the Bay of Bengal (Rahaman, 2009).

In present-day, river pollution is a serious and emerging problem in the majority of developing countries. Due to rapid industrialization, there has been an increase in the amount of effluent being disposed of in natural water bodies. Industrial effluents and sewage entering the water bodies are one of the prime sources of environmental toxicity, which endangers aquatic biota and deteriorates water quality (Sinha and Paul, 2012; Sinha et al., 2016). The quality of water is a vital concern for mankind since it is directly linked with human welfare (Sinha and Paul, 2013). The industries, which emits the metals in electroplating industries, paint and pigment industries, ceramic pulp and paper industries, cotton textile, steel plant, galvanization of ion product, iron and mining industries. The polluted water may lead to the destruction of the beneficial species either directly by affecting the aquatic forms of life or indirectly through breaking the biological food chains such as fish and their habitat and behavioral pattern (Prakash and Verma, 2014; Verma and Prakash, 2019).

Various environmental factors such as temperature, $\mathrm{pH}$, water hardness, dissolved oxygen light, salinity and organic matter can influence the toxicity of the metals in the solution. As a result, metals shift from one compartment within the aquatic environment to another including the biodata often with detrimental effects, through sufficient bioaccumulation. Metals are introduced into the aquatic system as a result of weathering of soil and rocks, from volcanic eruptions and from a variety of human activities involving mining, processing use of metals or substances containing metal contaminants (Prasad and Ruapanwar, 1990). Trace metals entering natural water become part of the water-sediment system and their distribution processes are controlled by a dynamic set of physical-chemical equilibria. The metal solubility is principally controlled by $\mathrm{pH}$, concentration and type of ligands and chelating agents, oxidation-state of mineral components and the redox environment of the system (Beg and Ali, 2008). As a result of adsorption and accumulation the concentration of metals in bottom sediments is expected to be higher than in the water above and this sometimes can cause secondary pollution problems, therefore, bottom sediments are repositories of heavy metals. Metals in natural waters can exist in truly dissolved colloidal and suspended forms. The proportion of these forms varies with metals and for different water bodies. Consequently, the toxicity and sedimentation potential of metals change depending on their forms. These wastes contain health hazard chemicals like salts of chromium, copper, cadmium, arsenic, mercury and lead which interact with aquatic environments and affect the river ecosystem. Sediments are regarded as the ultimate sink and indicator of changes in water column as well as the influence of anthropogenic activities in air and watersheds (Ramesh et al.,1990). Heavy metals of anthropogenic origin enter into the rivers as inorganic complexes or hydrated ions, which are easily adsorbed on surface of sediment particles and constitute the labile fraction (Vukovic et al., 2014).

Environmental and ecosystem variables such as turbulence, water $\mathrm{pH}$, redox potential, seasonal flooding, and storms cause periodic remobilization of contaminated surface and thereby making the bottom sediments a potential source (Osakwe et al., 2014). Previous studies have shown that 30-98 \% of heavy metals in rivers are transported in sediment-associated forms (Wang et al., 2011).The length of the main channel from the traditional source of the Gangotri glacier in India is about $2550 \mathrm{~km}$. Industrial wastes with organic and inorganic chemical constituents change the physical appearance of river water. Therefore; physical appearance of the river water gradually becomes brown to blackish colour around Kanpur city where approximates 1000 MLD toxic 
effluents of about 400 tanneries, untreated municipal waste and industrially polluted Pondu river discharge their waste to river Ganga.

The fishes, best indicator of water body pollution, are the most sensitive of all aquatic animals. Fish is an important source of protein and easily digestible food for human being. It plays a vital role to fulfill our nutritional requirement. However, now a days due to different natural and anthropogenic activities, fish production in natural waterbodies are declined due to unexpected temperature variation, unfavorable $\mathrm{pH}$, dissolved oxygen, dissolved solids, application of pesticides and biological agents like parasites, bacteria, virus, fungus etc. are the main causes of declining the fish population (Kaur and Mishra, 2019; Prakash, 2020). Haematological and biochemical parameters are the most assessable body contents for checking the toxicity of any chemicals. Any alternation in biochemical parameters can result in serious outcomes in the form of various diseases in both the animal and its consumers (Verma and Prakash, 2019;Prakash and Verma, 2020a,b \& 2021).

\section{Sources of heavy metal}

"Heavy metals" is a collective term, which applies to the group of metals and metalloids with an atomic density greater than $4 \mathrm{~g} / \mathrm{cm} 3$, or 5 times or more, greater than water (Hawkes, 1997; Miret al., 2020).Heavy-metal contamination is not a modern problem arising out of industrialization e it began when humans started processing ores (Renberg et al., 1994; Sharma et al., 2003). Since then the use of metals and their impacts on the environment have accelerated, with a major increase during the 19th and 20th centuries (Forstner and Wittman,1983). Generally, most of the heavy metals enter the inriver from different sources, it be can be either natural by erosion and weathering and or anthropogenic (Gupta et al., 2013; Sheykhi and Moore, 2016) (Fig. 1). In view of the intense human activity, natural sources of heavy metals from leaching and weathering of rocks in the environment, are usually of little importance (KabataPendias, 2001; Dixit et al., 2015). The presence of heavy metals in sediments is due to precipitation of their carbonates, hydroxides, and sulfides, which settle down and form the part of sediments. The most important anthropogenic sources of heavy metal are various industries and domestic sewage. The practice of discharging waste from industries and untreated domestic sewage into the aquatic ecosystem is continually going on that leads to the increase in the concentration of heavy metals in river water (Wang et al., 2011; Capangpangan et al., 2016). The industries which attribute heavy metals in river water are generally metal industries, paints, pigment, varnishes, pulp and paper, tannery, distillery, rayon, cotton textiles, rubber, thermal power plant, steel plant, galvanization of iron products and mining industries as well as unsystematic use of heavy metal-containing pesticides and fertilizer in agricultural fields (Sutharet al., 2009; Sindern et al., 2016). These heavy metals have accumulative effect at the low level in drinking water and groundwater (Prabha and Selvapathy,1997).

\section{Heavy metals and its effects}

Heavy metal in the aquatic environments has been as a potential threat to the aquatic organisms including fishes. Metals are known to inhibit the several biochemical and physiological mechanism vital for fish metabolism (Srivastava and Prakash, 2018; Prakash and Verma, 2019). The most important heavy metals from the point of view of water pollution are $\mathrm{Zn}$, As, $\mathrm{Cu}, \mathrm{Pb}, \mathrm{Cd}, \mathrm{Hg}, \mathrm{Ni}$, and $\mathrm{Cr}$. Some of these metals (e.g. $\mathrm{Cu}, \mathrm{Fe}, \mathrm{Mn}, \mathrm{Ni}$, and $\mathrm{Zn}$ ) are required as nutrients in trace amounts for life processes in plants and microorganisms but become toxic at higher concentrations (Table 1). Other such as $\mathrm{Pb}, \mathrm{Cr}$, and Cd has no known biological function, but are toxic elements (Dudka and Adriano, 1997; Ghannam et al., 2015). These heavy metals are not readily degradable in nature and accumulate in the animal as well as human bodies to a very high toxic amount leading to undesirable effects beyond a certain limit (Adakole and Abolude, 2012; Govind and Madhuri,2014). The fatal diseases such as eyelid edema, nephritis, renal tumour, extensive lesions in the kidneys, anuria, nasal mucous membranes and pharynx congestion, increase blood pressure and cardiovascular diseases, osteoporosis, cancer, headache and malfunctions of different systems of the body caused by heavy metals have been reported by several authors (Florea and Büsselberg,2006; Vaishaly et al., 2015). They are also known to interfere with synthesis and metabolism of the hormones (Sharma et al., 2014). Cadmium is widely used in the manufacture of batteries, metal and mining industry, dentistry etc. because of its noncorrosive nature. It may be transported to aquatic ecosystems as a result of both natural (weathering and erosion) and anthropogenic (industrial and 
agricultural) activities. Its exposure leads to various diseases such as cardiovascular, hypertension, chronic kidney disease, lung and prostate cancer (Kumar et al., 2019). Copper $(\mathrm{Cu})$ is an essential trace metal and micronutrient for cellular metabolism in living organisms on account of being a key constituent of metabolic enzymes. However it can be extremely toxic to intracellular mechanisms in aquatic animals at high concentrations which exceed normal levels (Singh, 2020).

\section{MATERIALSAND METHODS}

\section{Study area}

The river Ganga at Kanpur lies at $80^{\circ} 22^{\prime}$ E longitudinal and $26^{\circ} 28^{\prime} \mathrm{N}$ latitudinal. Kanpur is situated on the bank of river East direction. So Kanpur city area decided with Ganga river in south direction flowing from West to East direction. Four experiment sites have been selected for the study purpose of Ganga river water at Kanpur of different stretches. The flows of Ganga river near Kanpur city area covered near about $14 \mathrm{Km}$ distance from S1 site to site S4 near the bridge name S1- Shuklaganj, S2- Jajmau, S3- Ganga barrage and S4- Sarsaiyya Ghat.

\section{Sample collection}

Water samples were collected from the Ganga river from upstream and downstream in sterile containers and transported to the laboratory on ice. All glass wares

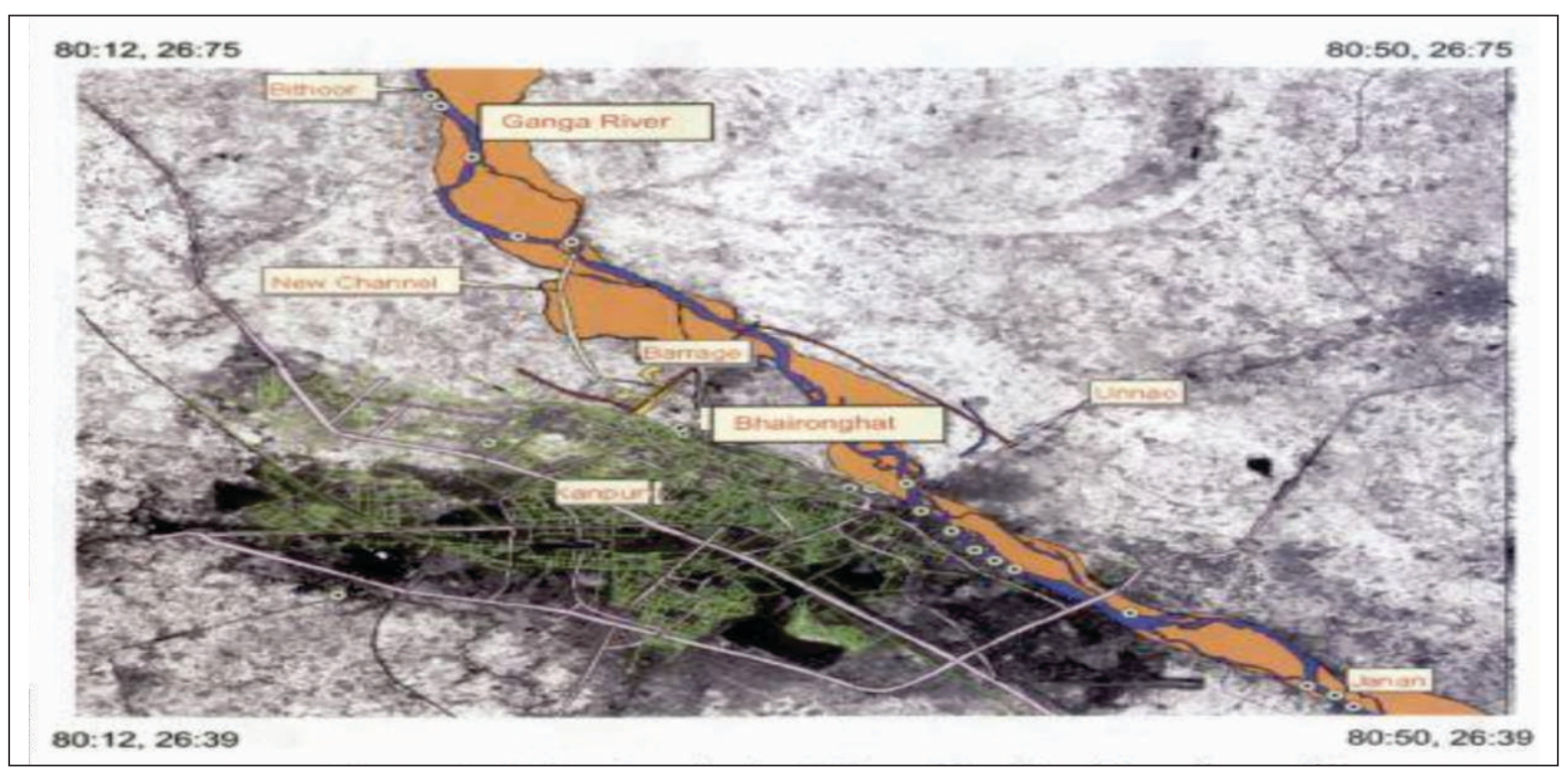

Fig.1: NIR band (0.76-0.8 am) of Aster image showing the course of River Ganga between Kanpur and Unnao.

were properly cleaned with acid cleaning agents and rinsed thoroughly with distilled water. The water samples were collected from four sampling stations. The analysis was carried out twice on the basis of six months intervals. First analysis was carried out in September 2019 and another analysis was carried out in February 2020.

\section{Determination of heavy metals}

In sample $5 \mathrm{~mL}$ conc. HNO3 was added to minimize adsorption of the metals on the container metals. For the analysis of heavy metals, one liter of sample along with $4 \mathrm{~mL}$ conc. HNO3 was evaporated in a beaker on a water bath to approximately $50 \mathrm{~mL}$ and then cooled. The concentrate was transferred to a $100 \mathrm{~mL}$ measuring cylinder and $2 \mathrm{~mL}$ conc. $\mathrm{HCl}$ was added. The solution was added to $100 \mathrm{~mL}$ with distilled water. The acidified samples were then analysed for heavy metals with the help of Atomic Absorption spectrophotometer spectra AA 220G (Varian Pvt. Ltd., Hyderabad). The samples were directly aspirated into an air $\mathrm{C} 2 \mathrm{H} 2$ flame of an AAS and absorbance was measured at different wavelengths. The metals determined were iron $(\mathrm{Fe})$, copper $(\mathrm{Cu})$, zinc $(\mathrm{Zn})$, nickel (Ni), chromium (Cr) and lead (Pb). 


\section{RESULTSAND DISCUSSION}

\section{Heavy Metal Concentrations of the River}

The concentrations of the heavy metals in all the samples and its considered tributaries were measured as dissolved pollutants thus, elements passing through the $0.45 \mu \mathrm{m}$ filter paper, suspended sediments (elements in the cake on the filter paper after filtration), and easily available or labile pollutants (elements present in suspended materials settled to the river bed).

\section{Dissolved Metal Concentration}

The dissolved concentrations of heavy metals $(\mathrm{Cu}, \mathrm{Cr}$, $\mathrm{Fe}, \mathrm{Ni}, \mathrm{Zn}$ and $\mathrm{Pb}$ ) in water samples taken from the 4 sites along the River Ganga and the WHO standards for the various metals in fresh natural waters. Comparatively, the measured dissolved concentrations of heavy metals from all the sampling sites were above the WHO standards.

\section{$\operatorname{Iron}(\mathbf{F e})$}

The value of iron ranged from 3.0 to $6.3 \mathrm{mg} / \mathrm{L}$, which was found to be above the permissible limits. The highest value was reported in winters and lowest in summers. Varied results were obtained with the range of $0.69-1.28 \mathrm{mg} / \mathrm{L}$. Lower values were obtained $(0.7$ $\mathrm{mg} / \mathrm{L}$ ) of iron. The values of iron could be attributed to high concentration of iron in the soil. Iron has been mostly derived from metallic pollutants but anthropogenic sources of iron may be confined to effluent from industries like steel, milk and metal pipes. Similar results reported that the presence of iron well above the stated limit is objectionable because they leave stains of oxide or hydroxide on laundry, sanitary wares, rusting of pipes in the supply line.

\section{Copper(Cu)}

Copper value ranged from 13.13-20.35 mg/L, which is above the permissible limits. The minimum values of copper concentration were found in the winter season. Copper concentration ranged from 0.01-0.07 ppm. Copper is an essential metal required by almost all living organisms in some of their enzyme systems but higher concentration it works as essentially a pollutant. Copper is useful to the human body in very small concentration, but at higher concentration of 25 $\mathrm{mg} / 100$ gram copper can be poisonous. $\mathrm{Cu}$ is an essential component of numerous key metalenzymes, which are critical in melanin myelin formation and cross linking of collagen and Dustin. It plays a vital role in hematopoiesis maintenance of vascular and skeleton integrity and function of the nervous system.

\section{Zinc(Zn)}

In this study, the value of Zn determined was 7.5-15.20 $\mathrm{mg} / \mathrm{dl}$, which was found to be above the permissible limit (WHO 1993) but falls within the range of (BIS 2005). Zinc is an essential component in human metabolism. But excessive concentration in drinking water may cause undesirable aesthetic effects. Deficiency of zinc in the human body may result in infantilism and impaired wound healing. The high values could be attributed to the human activities such as use of chemicals and zinc based fertilizers.

\section{Nickel(Ni)}

In this study, the concentration of ranged from (1.2 to $3.9 \mathrm{mg} / \mathrm{L}$ ), which was found to be above the permissible limits. Ni interacts with organic matter and settles down, resulting in its higher concentration in sediments. Minimum concentration of $\mathrm{Ni}$ in river water was recorded upstream at Ghazipur while maximum value of $\mathrm{Ni}$ was obtained downstream at Kanpur. Higher as well as lower concentrations of the heavy metal in drinking water are equally harmful to human beings.

\section{Chromium(Cr)}

In this study, chromium value ranged between 1.2 to $5.8 \mathrm{mg} / \mathrm{L}$ of water, which is greater than the permissible limit. Higher concentration of $\mathrm{Cr}$ in water causes disorder of skin and respiratory tract. Higher concentration of chromium in rivers near Kanpur is due to the presence of dairies, sugar, opine and other industries. The maximum value of chromium may be attributed to huge amount of domestic sewage with organic pollutant is disposed into the river.

\section{Lead (Pb)}

The study evaluated the range of lead in all the four sampling stations is the range of $2.05-5.20 \mathrm{mg} / \mathrm{L}$, which is above the permissible limit. Lead is higher toxic metal and its concentration in natural water increases mainly through anthropogenic activities. The source of lead in surface as well as in ground water is through large no. of industries such as batter manufactures, paints, ceramics, pesticides, cable insulation and plastic which use lead in their operation. It is known to be an accumulative type of poison in the human body. Varied results were obtained at different sampling stations in water of Ganga in Kanpur. Lead may enter into the sewage system through dust, soil erosion, leaching urban waste discharges and run off from steels and other surfaces. This toxic metal may cause anemia, kidney disease and nervous disorder above the tolerance limits $0.05 \mathrm{mg} / \mathrm{L}$. 
Table 1: Heavy metal analysis by AAS at different wavelength of different sampling.

\begin{tabular}{|l|c|c|c|c|c|c|}
\hline $\begin{array}{l}\text { Sampling } \\
\text { Sites }\end{array}$ & Fe 248.3 nm & Cu 324.8 nm & Zn 213.9nm & Ni 232 nm & Cr 358 nm & Pb 217 nm \\
\hline S1 & 4.1 & 13.13 & 7.52 & 2.9 & 3 & 2.05 \\
\hline S2 & 3 & 15.5 & 9.9 & 2.2 & 12 & 2.8 \\
\hline S3 & 4.2 & 17.8 & 11.2 & 5.2 & 3.5 & 4.1 \\
\hline S4 & 4.4 & 15.23 & 10.5 & 3.4 & 3.8 & 4.2 \\
\hline BIS(2005) & $0.3-0.5$ & 1.5 & 1.5 & 0.02 & 0.05 & 0.1 \\
\hline WHO 1993 & 0.3 & 2 & 5 & 0.02 & 0.05 & $0 . .01$ \\
\hline Mean & 3.925 & 15.415 & 9.78 & 3.425 & 2.875 & 3.2875 \\
\hline S.D. & 0.629 & 1.91 & 1.597 & 1.281 & 1.164 & 1.042 \\
\hline C.V. & 16.03 & 12.39 & 16.34 & 37.2 & 40.5 & 31.72 \\
\hline \multicolumn{7}{|c|}{ S1-Dhukla Ganj, S2-Jajmau, S3-Ganga Barrage, S4-Bhairon Ghat, } \\
\hline \multicolumn{7}{|c|}{ Standard deviation, C.V.- Coefficient of variation } \\
\hline
\end{tabular}

Table 2: Heavy metal analysis by AAS at different wavelength of different sampling station in the year Feb $2020(\mathrm{mg} / \mathrm{l})$.

\begin{tabular}{|l|c|c|c|c|c|c|}
\hline $\begin{array}{l}\text { Sampling } \\
\text { Sites }\end{array}$ & Fe 248.3 nm & Cu 324.8 nm & Zn 213.9nm & Ni 232 nm & Cr 358 nm & Pb 217 nm \\
\hline S1 & 4.8 & 18.12 & 9.52 & 3.9 & 3.2 & 2.9 \\
\hline S2 & 3.4 & 17 & 10.01 & 3.2 & 2.2 & 3.8 \\
\hline S3 & 5.8 & 20.35 & 15.2 & 6.2 & 3.8 & 4.4 \\
\hline S4 & 6.3 & 16.23 & 12.5 & 4.4 & 5.8 & 5.2 \\
\hline BIS(2005) & $0.3-0.5$ & 1.5 & 1.5 & 0.02 & 0.05 & 0.1 \\
\hline WHO 1993 & 0.3 & 2 & 5 & 0.02 & 0.05 & $0 . .01$ \\
\hline Mean & 5.075 & 17.925 & 11.8075 & 4.425 & 3.75 & 4.075 \\
\hline S.D. & 1.278 & 1.793 & 2.611 & 1.281 & 1.517 & 0.97 \\
\hline C.V. & 25.2 & 10 & 22.11 & 28.96 & 40.47 & 23.82 \\
\hline \multicolumn{7}{|c|}{ S1-Shukla Ganj, S2-Jajmau, S3-Ganga Barrage, S4-Bhairon Ghat, } \\
\hline
\end{tabular}

From the above values of mean, S.D. and coefficient of variation (Table 1) shows that the coefficient of $\mathrm{Cr}$ in water samples of different sampling stations was consistent followed by concentration of $\mathrm{Cu}$ and $\mathrm{Zn}$. There is very little variation in the concentration of these metals between different sampling stations. C.V. value of $\mathrm{Cr}(40.5 \%)$ showed high variation in the concentration values of $\mathrm{Cr}$ at different sampling stations. Followed by $\mathrm{Ni}$ and Fe, which also shows high variation in concentration at different sampling stations. From the above values of means, S.D. and coefficient of variation (Table 2) shows that the concentration of $\mathrm{Cr}$ in water samples at different sampling stations was consistent i.e. very less variation in concentration of $\mathrm{Cr}$ at different sampling sites followed by Zn and Ni. C.V. value of Cr shows high 
variation in the concentration of $\mathrm{Cr}$ at different sampling stations followed by $\mathrm{Fe}$ and $\mathrm{Pb}$, which also show high variation in the concentration at different sampling stations.

\section{CONCLUSION}

The overall results of this study show that heavy metal concentration in river sediment is rising. Spatial distribution showed different degrees of pollution and a consistently rising trend downstream, indicating strong influence of local sources including agricultural and untreated urban-industrial wastewater. A number of micro- and macro drains add untreated urban-industrial wastewater in the river at different points along the city. These drains need to be checked and wastewater to be properly treated. We conclude that holy river Ganga water is may be not fit for drinking and its basic requirement to be treated to reduce the pollution specific heavy metals. Heavy metals extraction is a serious problem as well as very costly. Heavy metals in water cause many serious. Biochemical problems in human health. Most components of electronic equipment are made up of heavy metals. The crude way of recycling them releases much more of the heavy metals into both the soil and the water environment. There is a need to maintain control on disposal of industrial waste in water bodies and to biomonitor the trace elements in the water and other eatables. The practice of trace element detection should be continued to avoid possible consumption of contaminated eatables. It is recommended that awareness should be spread among the people regarding the hazards on consumption of polluted water and related eatables. Metal concentration showed the influence of seasonal pattern in hydrological discharge. All metals exceed their base levels and show moderate to severe enrichment downstream, suggesting the role of local factors and the need to screen sources of such metals to the river for adopting appropriate control measures.

\section{REFERENCES}

1. Adakole, J.A. and Abolude, D.S. (2012). Pollutional status of Kubanni Lake through metal concentrations in water and sediment columns, Zaria, Nigeria, Res. J. Environ. Earth Sci. 4:424e427.

2. Beg, K. R. and Ali, S. (2008).Chemical Contamination and Toxicity of Ganga River
Sediment from up and Down Stream Area at Kanpur, American J. Environ. Sci., 4(4), 362-366.

3. Behera S., Areendran G., Gautam P. and Sagar V. (2011). For a living Ganga working with people and aquatic species. New Delhi, WWF-India, 184.

4. Capangpangan, R.Y., Pagapong, N.K., Pineda, C.P. and Sanchez, P.B. (2016). Evaluation of potential ecological risk and contamination assessment of heavy metals in sediment samples using different environmental quality indices case study in Agusanriver, Caraga Philippines, J. Biodiver. Environ. Sci. 8: 1e16.

5. Das, P. and Tamminga, K.R. (2012). The Ganges and the GAP: an assessment of efforts to clean a sacred river, Sustainability 4: 1647-1668.

6. Dixit, R., Malaviya, D., Pandiyan, K., Singh, U.B., Sahu, A., Shukla, R., Singh, B.P., Rai, J.P., Sharma, P.K., Lade, H. and Paul, D. (2015). Bioremediation of heavy metals from soil and aquatic environment: an overview of principles and criteria of fundamental processes, Sustainability 7:2189e2212.

7. Dudka, S. and Adriano, D.C. (1997). Environmental impacts of metal ore mining and processing: a review, J. Environ. Qual. 26: $590 \mathrm{e} 602$.

8. Florea, A.M. and Büsselberg, D. (2006). Occurrence, use and potential toxic effects of metals and metal compounds, Biometals19: $419 \mathrm{e} 427$.

9. Forstner, U. and Wittman, G. (1983). Metal Pollution in the Aquatic Environment, $€$ SpringerVerlag, New York.

10. Ghannam, H.E., El Haddad, E.S. and Talab, A.S. (2015). Bioaccumulation of heavy metals in tilapia fish organs, J. Biodivers. Environ. Sci. 7: 88e99.

11. Gopal, B. (2000). River conservation in the Indian subcontinent, in: P.J. Boon, B.R. Davies, G.E. Pelts (Eds.), Global Perspectives on River Conservation: Science, Policy and Practice, Wiley, London, pp. 233-261.

12. Goswami D. N., Gautam Y.P. and Kumar A. (2021). Evaluation of Ganges water quality and its suitability for Agriculture use from Rishikesh to 
Prayagraj, India. International Journal of Biological Innovations. 3(2):417-421. https:// doi.org/10.46505/IJBI.2021.3225

13. Govind, P. and Madhuri, S. (2014). Heavy metals causing toxicity in animals and fishes, Res. J. Anim. Vet. Fish. Sci. 2: 17e23.

14. Gupta, N., Yadav, K. K., Kumar, V. and Singh, D. (2013). Assessment of physicochemical properties of Yamuna river in Agra city, Int. J. Chem. Tech Res. 5: 528e531.

15. Hawkes, J.S., (1997). What is a "heavy metal”, J. Chem. Educ.74:1374.

16. Kabata-Pendias, A. (2001).Trace Elements in Soils and Plants, CRC Press, Boca Raton, Florida, USA,.

17. Kalal V., Giri M.J., Baskar S. and Kuba R. (2021). Detection of Pollutants present in the surface water of Ayad River, Udaipur, Rajasthan. International Journal of Biological Innovations. 3 (1): 212-220. https://doi.org/ 10.46505/ IJBI.2021.3123

18. Kaur G. and Mishra B. K. P. (2019). Histopathological changes in Liver of fish Channa punctatus exposed to sub lethal concentration of Hybrid Pesticide. International Journal of Biological Innovations. 1(2): 83-86. https://doi.org/10.46505/IJBI.2019.1209.

19. Kumar A., Prakash S. Parmar A. and Bajpeyee A. K. (2019). Effect of cadmium on fresh water teleost, Heteropneustesfossilis(Bloch). International Journal of Biological Innovations. 1 (1):14-17. https://doi.org/ 10.46505/ IJBI.2019.1103

20. Mir M.A., Arya S. and Kak A. M. (2020). Health Risk assessment of Heavy Metals for population via consumption of Pulses and Cereals. International Journal of Biological Innovations. 2 (2): 241-246. https://doi.org/ 10.46505/ IJBI.2020.2222.

21. Osakwe, J. O., Adowei, P. and Jnr, M. H. (2014). Evaluation of heavy metal species in bottom sediments from Imo River system, Southeastern Nigeria. Res J Chem Sci., 4(6):23-30.

22. Prabha, S. and Selvapathy, P. (1997). Toxic metal pollution in Indian Rivers, Indian $J$. Environ. Prot. 17:641e649.
23. Prakash S. and Verma A.K. (2020a). Effect of Arsenic on Serum Biochemical parameters of a fresh water cat fish, Mystusvittatus. International Journal of Biological Innovations. 2 (1): 1119.https://doi.org/10.46505/IJBI.2020.2102

24. Prakash S. and Verma A.K. (2020b). Toxic Effects of Paper Mill Effluents on Mortality, Behaviour and Morphology of Snake Headed Fish, Channapunctatus (Bloch.). International Journal of Biological Innovations. 2 (2): 102-108. https://doi.org/10.46505/IJBI.2020.2204.

25. Prakash S. and Verma A. K. (2021). Arsenic: It's Toxicity and Impact on Human health. International Journal of Biological Innovations. 3 (1): 38-47. https://doi.org/ 10.46505/ IJBI.2021.3102.

26. Prakash, S. (2020). Toxic effect of chlorpyrifos pesticides on the behaviour and serum biochemistry of Heteropneustes fossilis (Bloch). International Journal on Agricultural Sciences. 11: 22-27.

27. Prakash, S. and Verma, A.K. (2014). Effect of Organophosphorus Pesticide (Chlorpyrifos)on the Haematology of Heteropneustes fossilis (Bloch). International Journal of Fauna and Biological Studies. 1(5):95-98.

28. Prakash, S. and Verma, A.K. (2019).Acute Toxicity and Behavioural Responses in Arsenic exposed Mystus vittatus (Bloch). International Journal on Agricultural Sciences 10 (1 \& 2): 1-3.

29. Prasad, S. and Ruapanwar, D. C. (1990). Separation of Selected Heavy Metals from Bank Sediment of River Ganga by Solvent Extraction, Pollution Research, 9(1-4), 15-21.

30. Rahaman, M.M. (2009). Integrated Ganges basin management: conflict and hope for regional development, Water Policy 11:168-190.

31. Ramesh, R., Subramanian, V. and Grieken, R.V. (1990). Heavy metal distribution in sediments of Krishna River basin. Environ Geol Water Sci 15:207-216.

32. Renberg, I., Persson, M.W. and Emteryd, O. (1994). Pre-industrial atmospheric lead contamination detected in Swedish lake sediments, Nature 368: 323e326.

33. Sharma, B., Singh, S. and Siddiqi, N.J. (2014). Biomedical implications of heavy metals induced 
imbalances in redox systems, Biomed. Res. Int. 2014: 640754.

34. Sharma, M. Tobschall, H. and Singh, I. (2003). Environmental impact assessment in the Moradabad industrial area (rivers RamgangaGanga interfluve), Ganga Plain, India, Environ. Geol. 43:957e967.

35. Sheykhi, V. and Moore, F. (2016). Environmental risk assessment of heavy metals pollution in aquatic ecosystem-a case study: sediment of Korriver, Iran, Hum. Ecol. Risk. Assess. 22899e910.

36. Sindern, S., Tremohlen, M., Dsikowitzky, L., Gronen, L., Schwarzbauer, J., Siregar, € T.H., Ariyani, F. and Irianto, H.E. (2016). Heavy metals in river and coast sediments of the Jakarta Bay region (Indonesia)-geogenic versus anthropogenicsources, Mar. Pollut. Bull. 110: $624 \mathrm{e} 633$.

37. Singh P.R. and Verma A.K. (2016). Observations on Hydrobiological Conditions of River Ganga at Daraganj, Allahabad. The Journal ofZoology Studies. 3(4): 81-82.

38. Singh R. (2020). Calcium in Plant Biology: Nutrient and Second Messenger. International Journal of Biological Innovations. 2(1): 31-35. https://doi.org/10.46505/IJBI.2020.2105.

39. Sinha, S.N. and Paul, D and. Biswas, K. (2016). Effects of Moringaoleifera Lam. and Azadirachta indica A. Juss. leaf extract in treatment of tannery effluent, Our Nat. 14: 47-53.

40. Sinha, S.N. and Paul, D. (2012). Detoxification of heavy metals by biosurfactants, Bull. Environ. Sci.Res. 1: 1-3.

41. Sinha, S.N. and Paul, D. (2013). Impact of sewage water on seed germination and vigour index of Cicerarietinum L. and Pisum sativum L, Int. J. Food Agric. Vet. Sci. 3 (2013) 19e26.

42. Srivastava N. K. and Prakash S. (2019). Effect of Zinc on the Histopathology of Gill, Liver and
Kidney of Fresh Water Catfish, Clariasbatrachus (Linn.). International Journal of Biological Innovations. 1 (1): 8-13. https://doi.org/ 10.46505/IJBI.2019.1102.

43. Suthar, S., Nema, A.K., Chabukdhara, M. and Gupta, S.K. (2009). Assessment of metals in water and sediments of Hindonriver, India: impact of industrial and urban discharges, J. Hazard. Mater 171:1088e1095.

44. Vaishaly, A.G., Mathew, B.B. and Krishnamurthy, N.B. (2015). Health effects caused by metal contaminated ground water, Int. J. Adv. Sci. Res. 1: 60e64.

45. Verma, A.K. and Prakash, S. (2019). Impact of arsenic on haematology, condition factor, Hepatosomatic and gastrosomatic index of a fresh Water cat fish, Mystusvittatus. International Journal on Biological Sciences .10 (2): 49-54.

46. Verma A.K. and Prakash S. (2020). E-wastes and their impact on environment and public health. International Journal of Applied Research. 6(9): 164-168.

47. Vukovic, D., Stankovic, S. J., Vukovic, Z. and Jankovic, K. (2014). Transport and storage of heavy metals in the Sava River Basin in Serbia. $J$ Serbian Chem Soc 79(3):379-387.

48. Wang, Y., Yang, Z., Shen, Z., Tang, Z., Niu, J. and Gao, F. (2011). Assessment of heavy metals in sediments from a typical catchment of the Yangtze River, China. Environ Monit Assess172(1-4):407-417.

49. Wang, Y., Yang, Z., Shen, Z., Tang, Z., Niu, J. and Gao, F. (2011). Assessment of heavy metals in sediments from a typical catchment of the Yangtze river, China, Environ. Monit. Assess. 172:407e417.

50. Welcomme, R.L. (1985). River Fisheries, Food and Agriculture Organization, Technical paper 262, Rome, Italy. 